\title{
Feeding Practices and Associated Factors During Diarrheal Disease Among Children Aged Less Than Five Years: Evidence from the Ethiopian Demographic and Health Survey 2016
}

This article was published in the following Dove Press journal:

Pediatric Health, Medicine and Therapeutics

\section{Chalie Tadie Tsehay \\ Andualem Yalew Aschalew \\ Endalkachew Dellie ID \\ Tsegaye Gebremedhin \\ Department of Health Systems and Policy, Institute of Public Health, College of Medicine and Health Sciences, University of Gondar, Gondar, Ethiopia}

Correspondence: Andualem Yalew Aschalew

University of Gondar, P. O. Box: 196,

Gondar, Ethiopia

Tel +251918151825

Email yalewandualem@gmail.com
Purpose: Diarrhea is a common childhood illness and one of the leading causes of death in young children globally. In Ethiopia, a significant number of deaths and hospitalizations in under-five children are related to diarrheal diseases. Inappropriate feeding during diarrhea leads to a double burden of diarrhea recurrence and malnutrition among children. However, empirical evidence is limited in Ethiopia. Thus, this study was aimed to assess feeding practices and associated factors during diarrheal disease among children aged less than five years in Ethiopia.

Patients and Methods: The study used the Ethiopian Demographic and Health Survey (EDHS) 2016 data. A two-stage stratified sampling technique was applied to identify 917 under five years children. Generalized linear mixed model analyses were computed, and a $\mathrm{P}$ value of less than 0.05 and an adjusted odds ratio (AOR) with a $95 \%$ confidence interval (CI) were used to identify statistically significant factors with feeding practices.

Results: The majority (92.5\%) of mothers were married. Out of the participants, $(54.1 \%)$ of children were male; $55.6 \%$ of them were in the age group of 6-23 months. The appropriate feeding practices for children aged less than five years who had diarrhea was $15.4 \%(95 \%$ CI: $13.7 \%-18.2 \%$ ). Mothers aged 25-34 years (AOR: 0.6, 95\% CI: $0.4-0.9$ ), agricultural occupation of mothers (AOR: 2.2, 95\% CI: 1.3-3.6), mothers attended four and more antenatal visit (AOR: 2.3, 95\% CI: 1.3-4.32) and mothers who had a postnatal checkup within two months of birth (AOR: $1.9,95 \% \mathrm{CI}: 1.1-3.2$ ) were factors statistically associated with child feeding practices during diarrhea.

Conclusion: Less than one-fifth of under-five children practiced appropriate feeding during diarrheal disease. Working in agriculture and attending antenatal care and postnatal checkup within two months were positively influencing feeding practice. Therefore, the government of Ethiopia needs to strengthen the existing maternal and child health services.

Keywords: feeding practices, diarrheal disease, under-five children, Ethiopia

\section{Introduction}

Globally, in 2018, an estimated 5.3 million under the age of 5 years children were died, mostly from preventable causes and almost half of the deaths have occurred within the first month of life. ${ }^{1}$ Sub-Saharan Africa (SSA) and Southern Asia were accounting over $80 \%$ of the under-five death. ${ }^{2}$ In Ethiopia, 1 in 15 children died before reaching the fifth birthday. ${ }^{3}$ Diarrhea is a common illness and the second leading cause of death in young children. ${ }^{4}$ About $19 \%$ of under-five deaths, 
globally, and $30 \%$ of pediatric admission in developing countries are related to diarrheal disease. ${ }^{5-7}$ In Africa diarrhea among young children accounts for the biggest reason for disease and nearly $50 \%$ of deaths among young children occurs because of diarrhea. ${ }^{8}$ Ethiopia is one of the five countries with the highest diarrheal disease burden among children under the age of five years. Studies in Ethiopia have revealed that diarrheal disease accounts for approximately $8.4 \%$ to $27 \%$ of all under-five deaths. Moreover, $16 \%$ of all under-five hospitalizations and $14 \%$ of all outpatient visits were due to diarrheal disease. $^{9,10}$

Inappropriate feeding during diarrhea leads to a vicious cycle for the frequent occurrence of diarrhea and malnutrition, which aggravates morbidity, mortality as well as interfere with physical growth and cognitive development. ${ }^{11,12}$ Evidences advocate that optimal child feeding practices (both liquid and solid foods) during childhood illnesses like diarrhea are among the foremost effective global strategies of integrated management of childhood illnesses and emphasize the necessity to extend fluid intake during illness while feeding is maintained and increase food intake during convalescence. ${ }^{13-17}$ Continuing feeding from the early onset of diarrhea can alleviate the consequences of the disease such as reduction of absorption and loss of nutrients, thereby the large portion of child death, due to diarrheal disease, can be prevented. $^{7,18}$

However, children's nutritional status can be worsened during or after illness unless they do not get extra food. Children's poor appetite induced by diarrhea can contribute to continuing the cycle of infection and stunting. ${ }^{19}$ Regardless of multi-dimensional advantages of continuous feeding of children during diarrheal disease, some traditional beliefs, and practices such as partial food restrictions, ceasing of breast milk, giving foods in a particular composition and a specific amount, restriction of vegetables and fruits ${ }^{4}$ are contributing factors for inappropriate feeding practices during common childhood illnesses in low-income and middle-income countries. ${ }^{20,21}$ Moreover, poor socioeconomic status, large family size, previous experience of child illness and death; poor educational status of caregivers, low maternal and child health services utilization; low coverage, and poor quality of primary health care services were the foremost commonly mentioned factors affecting child feeding practices during and after diarrheal disease. ${ }^{22,23}$ A study done in that of rural pastoralist communities of the Afar region, Ethiopia showed, only $5.2 \%$ of children with diarrhea were offered foods more than usual. ${ }^{23}$ In spite of multiple site-specific studies, national-level studies would also have a paramount contribution to the achievement of the national target regarding child health, however, child feeding practices and associated factors during diarrheal disease is remained unstudied in Ethiopia. Thus, this study aimed to examine child feeding practices during diarrheal diseases and associated factors among children aged less than five years in Ethiopia using evidence from EDHS, 2016.

\section{Methods}

\section{Study Settings and Data Source}

The dataset for this analysis was 2016 Ethiopian Demographic and Health Survey (EDHS), conducted between January and June 2016. The data is a nationally representative household survey that has been implemented by the Central Statistical Agency (CSA) of Ethiopia with technical assistance from ICF DHS Program. ${ }^{24}$ Ethiopia is divided into two administrative cities and nine geographical regions. The study involves all nine regions and two administrations cities.

\section{Sampling Procedures}

The sampling frame used for the 2016 EDHS is the Ethiopia Population and Housing Census, which was conducted in 2007 by the CSA of Ethiopia. The census had used a complete list of 84,915 enumeration areas (EAs) created for 2007. The sampling frame contains the EAs location, type of residence, and the estimated number of residing households.

The 2016 EDHS was stratified and selected in two stages. The regions were stratified into urban and rural areas (yielded 21 sampling strata). Samples of EAs were selected independently in each stratum. At each of the lower administrative levels, implicit stratification and proportional allocation were achieved within each sampling stratum using a probability proportional to size selection. First, a total of 645 EAs were selected with probability proportional to the EAs size and with independent selection in each sampling stratum with the sample allocation given. The total residing households in the EAs were the EA size, and a household listing operation was implemented, which can be served as the sampling frame for the selection of households in the second stage. If the selected EA was large with more than 200 households segmentation was 
done to minimize the task of household listing. Through the probability proportional to the segment size, only a segment was selected for the survey, and the household listing was conducted for each selected segment.

In the second stage, a fixed number of 28 households from each cluster were selected with an equal probability using a systematic selection from the newly created household listing. The survey interviewer interviewed only preselected households. No replacements or changes of the pre-selected households were allowed in the implementing stages to prevent bias. In this study, the 2016 Ethiopian demographic and health survey childhood datasets of the nine regions and two administrative cities were used.

All women aged 15-49 years who are the usual members of the selected households were eligible for the female survey. Children aged 0-59 months were the source population, whereas children aged 0-59 months with a history of diarrhea within two weeks before the survey were the study population. Accordingly, 917 mothers and their children aged 0-59 months with a history of diarrheal disease were included in the study, and data were extracted from the 2016 EDHS datasets. Potential independent variables were also extracted.

\section{Measurements of Variables}

Feeding practices during diarrheal disease was the dependent variable of the study. It was measured based on the amount of liquid and food given to children during diarrheal disease. Accordingly, if a child received both liquids and foods in more than the usual amount, it was classified as "appropriate feeding practices" otherwise as "inappropriate feeding practices". ${ }^{24}$ The information on feeding practices was collected from mothers' verbal responses. The mothers were asked about the feeding practices, treatments, and other actions taken for their child during diarrheal disease.

The explanatory variables were sociodemographic, economic, maternal, and child health services related characteristics and child-related variables.

In the EDHS, an asset-based approach was used to calculate the wealth index. The collected information was on ownership of a range of durable assets (eg car, refrigerator, and television) and housing characteristics (eg material of dwelling floor and roof and toilet facilities). Women were asked whether they had the above assets or not. These scores were derived using principal component analysis and ranked into the poorest, poorer, middle, richer, and richest categories. The wealth quintiles are expressed in terms of quintiles of individuals in the population rather than quintiles of individuals at risk for anyone's health or population indicator.

Media exposure was assessed as not at all, less than once in a week, and at least once a week; if they have access to all three media (newsletter reading, listen to the radio, and watching TV).

\section{Data Processing and Statistical Analysis}

The data were extracted, cleaned, re-coded, and analyzed using STATA version 14 (Stata Corp, College Station, TX). Descriptive statistics were presented using tables and narrations. The EDHS data has hierarchical nature: women are nested within a cluster and we expect that women within the same cluster may be more similar to each other than women in another cluster. This violates the assumption of the traditional regression model which is the independence of observations and equal variance across clusters. Therefore, an advanced statistical model is needed to take into account the between cluster variability to get a reliable standard error and unbiased estimate. Besides, since the outcome variable was binary, standard logistic regression, Generalized Linear Mixed Models (GLMM) were fitted, and model comparison, as well as model fitness, were done based on the Intra-Class Correlation Coefficient (ICC), Akaike Information Criteria (AIC), Bayesian Information Criteria (BIC), and Deviance values. Accordingly, the mixed-effect logistic regression model was the best-fitted model since it had the lowest deviance. Variables having a $\mathrm{P}$ value of less than 0.2 in the bivariable analysis were selected as candidate variables for the multivariable mixed-effect logistic regression analysis. In the final model, a $\mathrm{P}$ value of less than 0.05 and an adjusted odds ratio (AOR) with a 95\% confidence interval (CI) were used to declare statistically significant factors with feeding practice among under-five children with diarrheal disease.

\section{Ethical Considerations}

Ethical clearance for the 2016 EDHS was provided by the Ethiopian Health and Nutrition Research Institute (EHNRI) Review Board, the National Research Ethics Review Committee (NRERC) at the Ministry of Science and Technology, the Institutional Review Board of ICF International, and the communicable disease control (CDC). This study used secondary data sources from 2016 EDHS. Permission to use the EDHS data was obtained from the Measure DHS international program http://www.dhsprogram.com. This was done after being 
registered and sending the concept note of this study through the website to get permission from ICF international to access and use the dataset. After obtaining permission (author letter), the dataset was downloaded from https://dhsprogram.com/Data/terms-of-use.cfm on Apr 09, 2020. The data is publicly available and has no personal identifiers.

\section{Results}

\section{Sociodemographic and Economic Characteristics of Participants}

A total of 917 mothers/caregivers with their respective under five years were included in the study. Out of the participants, more than half $(52.2 \%)$ of women were aged 25-34 years; the majority of participants $(92.5 \%)$ were married, and the average family size was 5.8 . Of the participants, $81.2 \%$ were rural residents; approximately $(15.3 \%)$ were from the Oromia region and $43.1 \%$ of participants were Muslims by religious status. Regarding educational status, about $58.2 \%$ of women have no formal education. Furthermore, $30.6 \%$ and $17.5 \%$ of participants were in the poorest and poorer wealth status, respectively, and $54.9 \%$ of them had no work (Table 1 ).

\section{Obstetrics-Related Characteristics of}

\section{Participants}

The majority of mothers $(40.4 \%)$ had four and more antenatal care follow-up for the recent pregnancy. Out of them (54.6\%) were started their first antenatal care follow-up in the second trimester of their pregnancy. In addition, 58.5\% gave birth at home, and $88.7 \%$ of mothers did not seek a postnatal checkup. The majority of mothers $(62.2 \%)$ had 2-5 living children; $64.4 \%$ wanted more children. (Table 2 ).

\section{Child Characteristics and Common}

\section{Childhood Illnesses}

More than half of the children (54.1\%) were male; $55.6 \%$ of them were in the age group of 6-23 months, and 69.6\% were feeding breast. Concerning symptoms, $40.5 \%$ and $54.2 \%$ had cough and fever for the last two weeks preceding the survey, respectively (Table 3 ).

\section{Health Service and Information Accessibility and Other Factors}

Distance to get health facility was a big problem for more than half (53.4\%) of mothers, and $62.2 \%$ had not visited the
Table I Sociodemographic and Economic Characteristics of Participants in Ethiopia, $2016(n=917)$

\begin{tabular}{|c|c|c|c|}
\hline Variables & Category & $\begin{array}{r}\text { Frequency } \\
(n)\end{array}$ & $\begin{array}{r}\text { Percentage } \\
(\%)\end{array}$ \\
\hline $\begin{array}{l}\text { Age of } \\
\text { mothers/care } \\
\text { givers }\end{array}$ & $\begin{array}{l}15-24 \\
25-34 \\
\geq 35\end{array}$ & $\begin{array}{l}255 \\
479 \\
183\end{array}$ & $\begin{array}{l}27.8 \\
52.2 \\
20.0\end{array}$ \\
\hline Residence & $\begin{array}{l}\text { Urban } \\
\text { Rural }\end{array}$ & $\begin{array}{l}172 \\
745\end{array}$ & $\begin{array}{l}18.8 \\
81.2\end{array}$ \\
\hline Region & $\begin{array}{l}\text { Tigray } \\
\text { Afar } \\
\text { Amhara } \\
\text { Oromia } \\
\text { Somali } \\
\text { Benishangul } \\
\text { SNNPR } \\
\text { Gambela } \\
\text { Harari } \\
\text { Addis Ababa } \\
\text { Dire Dawa }\end{array}$ & $\begin{array}{r}114 \\
89 \\
108 \\
140 \\
64 \\
65 \\
144 \\
75 \\
43 \\
28 \\
47\end{array}$ & $\begin{array}{r}12.4 \\
9.7 \\
11.8 \\
15.3 \\
7.0 \\
7.1 \\
15.7 \\
8.2 \\
4.7 \\
3.0 \\
5.1\end{array}$ \\
\hline Religion & $\begin{array}{l}\text { Muslim } \\
\text { Orthodox } \\
\text { Others }^{\mathrm{a}}\end{array}$ & $\begin{array}{l}395 \\
305 \\
217\end{array}$ & $\begin{array}{l}43.1 \\
33.3 \\
23.7\end{array}$ \\
\hline $\begin{array}{l}\text { Sex of head of } \\
\text { households }\end{array}$ & $\begin{array}{l}\text { Male } \\
\text { Female }\end{array}$ & $\begin{array}{l}742 \\
175\end{array}$ & $\begin{array}{l}80.9 \\
19.1\end{array}$ \\
\hline $\begin{array}{l}\text { Family size } \\
(\text { mean =5.8) }\end{array}$ & $\begin{array}{l}\text { Below mean } \\
\text { Above mean }\end{array}$ & $\begin{array}{l}618 \\
299\end{array}$ & $\begin{array}{l}67.4 \\
32.6\end{array}$ \\
\hline $\begin{array}{l}\text { Current marital } \\
\text { status of } \\
\text { respondents }\end{array}$ & $\begin{array}{l}\text { Married } \\
\text { Not married }\end{array}$ & $\begin{array}{r}852 \\
65\end{array}$ & $\begin{array}{r}92.5 \\
7.5\end{array}$ \\
\hline $\begin{array}{l}\text { Educational } \\
\text { status of } \\
\text { respondents }\end{array}$ & $\begin{array}{l}\text { No education } \\
\text { Primary } \\
\text { education } \\
\text { Secondary } \\
\text { education } \\
\text { Higher education }\end{array}$ & $\begin{array}{r}534 \\
287 \\
66 \\
\\
\\
30\end{array}$ & $\begin{array}{r}58.2 \\
31.3 \\
7.2\end{array}$ \\
\hline $\begin{array}{l}\text { Educational } \\
\text { status of } \\
\text { partner's } \\
(=852)\end{array}$ & $\begin{array}{l}\text { No education } \\
\text { Primary } \\
\text { Secondary } \\
\text { Higher }\end{array}$ & $\begin{array}{r}353 \\
322 \\
106 \\
71\end{array}$ & $\begin{array}{r}41.4 \\
37.8 \\
12.4 \\
8.4\end{array}$ \\
\hline $\begin{array}{l}\text { Occupation of } \\
\text { respondents }\end{array}$ & $\begin{array}{l}\text { Not working } \\
\text { Sales \& service } \\
\text { Agriculture } \\
\text { Others }^{b}\end{array}$ & $\begin{array}{l}504 \\
141 \\
171 \\
101\end{array}$ & $\begin{array}{l}54.9 \\
15.4 \\
18.7 \\
11.0\end{array}$ \\
\hline $\begin{array}{l}\text { Partner's } \\
\text { occupation } \\
(n=852)\end{array}$ & $\begin{array}{l}\text { Not working } \\
\text { Professional } \\
\text { Agriculture } \\
\text { Others }\end{array}$ & $\begin{array}{r}79 \\
168 \\
446 \\
159\end{array}$ & $\begin{array}{r}9.3 \\
19.7 \\
52.3 \\
18.7\end{array}$ \\
\hline
\end{tabular}

(Continued) 
Table I (Continued).

\begin{tabular}{|l|l|r|r|}
\hline Variables & Category & $\begin{array}{r}\text { Frequency } \\
\text { (n) }\end{array}$ & $\begin{array}{r}\text { Percentage } \\
\text { (\%) }\end{array}$ \\
\hline \multirow{6}{*}{ Wealth status } & Poorest & 281 & 30.6 \\
& Poorer & 160 & 17.4 \\
& Middle & 149 & 16.3 \\
& Richer & 140 & 15.3 \\
& Richest & 187 & 20.4 \\
\hline
\end{tabular}

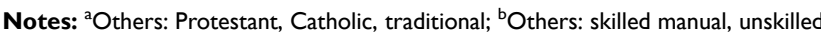
manual, do not know.

health facility for the last 12 months before the data collection period. Nearly all $(99.8 \%)$ of participants were not a member of health insurance. The majority of women $(89.1 \%)$ were no participating in decision making (Table 4 ).

\section{Feeding Practices During Diarrhea Among Children Aged Less Than Five Years}

Only $124(13.5 \%)$ and $56(6.1 \%)$ of children were offered to drink and eat more than the usual amount of liquids and foods, respectively. Appropriate feeding practice among children aged less than five years during diarrhea disease in Ethiopia was found to be $15.4 \%$ (95\% CI: 13.7-18.2).

\section{Factors Associated with Feeding Practices During Diarrhea Among Under-Five Children}

In the generalized linear mixed models analysis, mothers' age, occupation, number of antenatal care follow up and baby postnatal checkups were variables significantly associated with feeding practice during diarrhea for children aged less than five years.

Accordingly, mothers with the age group of 25-34 years were $40 \%$ less likely to feed their children appropriately compared to participants with the age group of 15-24 years (AOR: 0.6, 95\% CI:0.4-0.9). Mothers with agriculture occupations were 2.2 times more likely to feed their children compared to mothers with no work $(95 \%$ CI: 1.3-3.6). Mothers who had four and more antenatal visits were 2.3 times more likely to feed their children compared to those who had no antenatal care visit (95\% CI: 1.3-4.3). Mothers who had a postnatal checkup within two months after birth were 1.9 (95\% CI: 1.1-3.2) times more likely to give appropriate feeding compared to their counterparts (Table 5).
Table 2 Obstetric-Related Characteristics of Mothers in Ethiopia, $2016(n=917)$

\begin{tabular}{|c|c|c|c|}
\hline Variables & Categories & $\begin{array}{r}\text { Frequency } \\
\text { (n) }\end{array}$ & $\begin{array}{r}\text { Percentage } \\
(\%)\end{array}$ \\
\hline $\begin{array}{l}\text { Number of ANC } \\
\text { visit }\end{array}$ & $\begin{array}{l}0 \\
\mathrm{I}-3 \\
+4\end{array}$ & $\begin{array}{l}261 \\
285 \\
371\end{array}$ & $\begin{array}{l}28.5 \\
31.1 \\
40.4\end{array}$ \\
\hline $\begin{array}{l}\text { Time of Ist ANC } \\
\text { visit in Month } \\
(n=656)\end{array}$ & $\begin{array}{l}\text { Ist trimester } \\
\text { 2nd } \\
\text { trimester } \\
\text { 3rd trimester }\end{array}$ & $\begin{array}{r}232 \\
358 \\
66\end{array}$ & $\begin{array}{l}35.4 \\
54.6 \\
10.0\end{array}$ \\
\hline Current pregnancy & $\begin{array}{l}\text { No } \\
\text { Yes }\end{array}$ & $\begin{array}{l}799 \\
118\end{array}$ & $\begin{array}{l}87.1 \\
12.9\end{array}$ \\
\hline $\begin{array}{l}\text { Is current } \\
\text { pregnancy wanted } \\
(n=|| 8)\end{array}$ & $\begin{array}{l}\text { Then } \\
\text { Later } \\
\text { Not at all }\end{array}$ & $\begin{array}{l}76 \\
28 \\
14\end{array}$ & $\begin{array}{l}64.4 \\
23.7 \\
11.9\end{array}$ \\
\hline $\begin{array}{l}\text { Wanted when } \\
\text { became pregnant }\end{array}$ & $\begin{array}{l}\text { Then } \\
\text { Later } \\
\text { No more }\end{array}$ & $\begin{array}{r}694 \\
173 \\
50\end{array}$ & $\begin{array}{r}75.7 \\
18.9 \\
5.4\end{array}$ \\
\hline $\begin{array}{l}\text { Number of living } \\
\text { children }\end{array}$ & $\begin{array}{l}1 \\
2-5 \\
6+\end{array}$ & $\begin{array}{l}173 \\
570 \\
174\end{array}$ & $\begin{array}{l}18.9 \\
62.2 \\
18.9\end{array}$ \\
\hline $\begin{array}{l}\text { Age of the mother } \\
\text { at the first child in } \\
\text { years }\end{array}$ & $\begin{array}{l}<18 \\
18-24 \\
25+\end{array}$ & $\begin{array}{r}346 \\
505 \\
66\end{array}$ & $\begin{array}{r}37.7 \\
55.1 \\
7.2\end{array}$ \\
\hline $\begin{array}{l}\text { The desire for } \\
\text { more children }\end{array}$ & $\begin{array}{l}\text { Wanted } \\
\text { Undecided } \\
\text { No more } \\
\text { wanted }\end{array}$ & $\begin{array}{r}591 \\
32 \\
294\end{array}$ & $\begin{array}{r}64.4 \\
3.5 \\
32.1\end{array}$ \\
\hline Place of delivery & $\begin{array}{l}\text { Home } \\
\text { Institutional }\end{array}$ & $\begin{array}{l}536 \\
381\end{array}$ & $\begin{array}{l}58.5 \\
41.5\end{array}$ \\
\hline $\begin{array}{l}\text { Postnatal checking } \\
\text { within two months }\end{array}$ & $\begin{array}{l}\text { No } \\
\text { Yes }\end{array}$ & $\begin{array}{l}813 \\
104\end{array}$ & $\begin{array}{l}88.7 \\
11.3\end{array}$ \\
\hline $\begin{array}{l}\text { PNC service } \\
\text { provider }(n=104)\end{array}$ & $\begin{array}{l}\text { Doctor } \\
\text { Nurse } \\
\text { Midwife } \\
\text { HEW } \\
{ }^{\text {a Others }}\end{array}$ & $\begin{array}{r}13 \\
47 \\
13 \\
28 \\
3\end{array}$ & $\begin{array}{r}12.5 \\
45.2 \\
12.5 \\
26.9 \\
2.9\end{array}$ \\
\hline
\end{tabular}

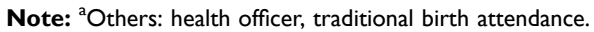

Abbreviations: ANC, antenatal care; PNC, postnatal care; HEW, health extension worker.

\section{Discussion}

In this study, the overall appropriate feeding practice was $15.4 \%$ and maternal age, mother's occupation, ANC, and PNC were associated with appropriate feeding practice.

The finding showed that a significantly low percentage of children, $13.5 \%$ and $6.1 \%$, have been given more than 
Table 3 Child Characteristics and Common Childhood Illness During Diarrhea in Ethiopia, $2016(n=917)$

\begin{tabular}{|l|l|r|r|}
\hline Variables & Categories & $\begin{array}{r}\text { Frequency } \\
\text { (n) }\end{array}$ & $\begin{array}{r}\text { Percentage } \\
\text { (\%) }\end{array}$ \\
\hline Sex of the child & Male & 496 & 54.1 \\
& Female & 421 & 45.9 \\
\hline Current age of the & $<6$ Months & 88 & 9.6 \\
child in months & $6-23$ & 510 & 55.6 \\
& $\geq 24$ & 319 & 34.8 \\
\hline Size of the child at & Large & 272 & 29.7 \\
birth & Average & 341 & 37.2 \\
& Small & 303 & 33.1 \\
\hline Child is twin & Single & 908 & 99.0 \\
& Multiple & 9 & 1.0 \\
\hline Currently, & Yes & 638 & 69.6 \\
breastfeed & No & 279 & 30.4 \\
\hline Had a fever in the & No & 497 & 54.2 \\
last two weeks & Yes & 420 & 46.8 \\
\hline Had a cough in the & No & 546 & 59.5 \\
last two weeks & Yes & 371 & 40.5 \\
\hline
\end{tabular}

Table 4 Health Service and Information Accessibility and Other Factors in Ethiopia, $2016(n=917)$

\begin{tabular}{|c|c|c|c|}
\hline Variables & Category & $\begin{array}{r}\text { Frequency } \\
(\mathrm{n})\end{array}$ & $\begin{array}{r}\text { Percentage } \\
(\%)\end{array}$ \\
\hline $\begin{array}{l}\text { Visited by } \\
\text { fieldwork for the } \\
\text { last } 12 \text { months }\end{array}$ & $\begin{array}{l}\text { No } \\
\text { Yes }\end{array}$ & $\begin{array}{l}626 \\
291\end{array}$ & $\begin{array}{l}68.3 \\
31.7\end{array}$ \\
\hline $\begin{array}{l}\text { Visit the health } \\
\text { facility for the } \\
\text { last } 12 \text { months }\end{array}$ & $\begin{array}{l}\text { No } \\
\text { Yes }\end{array}$ & $\begin{array}{l}347 \\
570\end{array}$ & $\begin{array}{l}37.8 \\
62.2\end{array}$ \\
\hline Health insurance & $\begin{array}{l}\text { No } \\
\text { Yes }\end{array}$ & $\begin{array}{r}915 \\
2\end{array}$ & $\begin{array}{r}99.8 \\
0.2\end{array}$ \\
\hline $\begin{array}{l}\text { Smoke or other } \\
\text { types of tobacco } \\
\text { use }\end{array}$ & $\begin{array}{l}\text { No } \\
\text { Yes }\end{array}$ & $\begin{array}{r}897 \\
20\end{array}$ & $\begin{array}{r}97.8 \\
2.2\end{array}$ \\
\hline $\begin{array}{l}\text { Participation in } \\
\text { decision making } \\
(=852)\end{array}$ & $\begin{array}{l}\text { No } \\
\text { Yes }\end{array}$ & $\begin{array}{r}759 \\
93\end{array}$ & $\begin{array}{l}89.1 \\
10.9\end{array}$ \\
\hline $\begin{array}{l}\text { Exposure to } \\
\text { mass-media on } \\
\text { a weekly base }\end{array}$ & $\begin{array}{l}\text { Not at all } \\
\text { Less than once } \\
\text { a week } \\
\text { At least once a } \\
\text { week }\end{array}$ & $\begin{array}{r}586 \\
263 \\
\\
68\end{array}$ & $\begin{array}{r}63.9 \\
28.7 \\
\\
7.4\end{array}$ \\
\hline $\begin{array}{l}\text { Distance to the } \\
\text { health facility }\end{array}$ & $\begin{array}{l}\text { Big problem } \\
\text { No big problem }\end{array}$ & $\begin{array}{l}490 \\
427\end{array}$ & $\begin{array}{l}53.4 \\
46.6\end{array}$ \\
\hline
\end{tabular}

usual liquid and food during diarrheal disease, respectively. This finding is consistent with the study in Peru. ${ }^{12}$ This might be explained by different factors like social and personal. For instance, a lack of knowledge about feeding practice and management during diarrhea. This is also supported that $58 \%, 64 \%$, and $62 \%$ of women had no education, media exposure, and did not visited by a community health worker, correspondingly. Moreover, food taboos might contribute to poor feeding practices. The previous finding showed that some foods such as mango, orange, and banana were restricted since they are believed to cause worms and diarrhea to the growing child. $^{25}$

A minimum acceptable diet is recommended for the growth and development of a healthy child. The study by Tassew AA et al from the latest Ethiopian Household Survey showed that around six percent of children aged 6-23 months took a minimum acceptable diet. ${ }^{26}$ This is comparable with the current finding of feeding despite the population was to some extent different. Another important point is a significant percentage of children had a fever $(54.2 \%)$ and $(40.5 \%)$ cough in addition to diarrhea, which might show the severity of diarrhea or other comorbidities like pneumonia. This might cause a loss of appetite and reduce feeding during the illness.

Evidence on feeding practice among children with diarrhea, at the national level, is limited, which makes direct comparison difficult with the current finding. Two-pocket studies in Burayu Town (53.6\%) and Mirab Abaya District (70.7\%), Ethiopia ${ }^{17,27}$ have higher feeding practice than ours. This could be explained by differences in the study population (those studies recruited less than two years) and the type of disease was any childhood illness. Besides, the current findings were from nationally representative data. Moreover, findings from DHS data in Bangladesh, India, Nepal, and Pakistan are higher than the current findings. Children's mothers in Bangladesh (21.7\%) were given a high amount of fluids, and children in Nepal, Pakistan, and Saudi Arabia were offered more amount of food and liquid. ${ }^{28,29}$

The odds of appropriate feeding practice among mothers aged 25-34 years were lower compared to mothers age between 15-24 years. Possibly, even if we have not information about the age of mothers at first birth, the earlier age group might have more children which might increase the mother's activity and responsibility. A study in Burayu corroborates the above explanation that mothers who had one child exercise appropriate 
Table 5 Generalized Linear Mixed Model Analysis of Factors Associated with Feeding Practices During Diarrhea Among Children Aged Less Than Five Years in Ethiopia, $2016(n=917)$

\begin{tabular}{|c|c|c|c|c|}
\hline \multirow[t]{2}{*}{ Variables } & \multicolumn{2}{|c|}{ Feeding Practices During Diarrhea } & \multirow[t]{2}{*}{ COR $(95 \% \mathrm{Cl})$} & \multirow[t]{2}{*}{ AOR $(95 \% \mathrm{Cl})$} \\
\hline & Appropriate n (\%) & Inappropriate $\mathbf{n}(\%)$ & & \\
\hline \multicolumn{5}{|l|}{ Age of participants } \\
\hline $15-24$ & $44(17.3)$ & $211(82.7)$ & I & 1 \\
\hline $25-34$ & $64(13.4)$ & $415(86.6)$ & $0.8(0.5-1.2)$ & $0.6(0.4-0.9) *$ \\
\hline 35 and above & $33(18.0)$ & $150(82.0)$ & I.I (0.6-1.9) & $0.9(0.5-1.6)$ \\
\hline \multicolumn{5}{|l|}{ Educational status } \\
\hline No education & $76(14.2)$ & $458(85.8)$ & I & I \\
\hline Primary & $45(15.7)$ & $242(84.3)$ & I.I (0.7-I.8) & I.I $(0.7-1.8)$ \\
\hline Secondary & $12(18.2)$ & $54(81.8)$ & $1.4(0.7-2.9)$ & $1.2(0.5-2.9)$ \\
\hline Higher & $8(26.7)$ & $22(73.3)$ & $2.4(0.9-6.3)$ & $2.3(0.7-7.3)$ \\
\hline \multicolumn{5}{|l|}{ Religion } \\
\hline Muslim & $55(13.9)$ & $340(86.1)$ & 1 & I \\
\hline Orthodox & $61(20.0)$ & $244(80.0)$ & $1.6(1.1-2.5)$ & I.I (0.7-I.7) \\
\hline Others $^{\mathrm{a}}$ & $25(11.5)$ & $192(88.5)$ & $0.8(0.5-1.4)$ & $0.7(0.4-1.3)$ \\
\hline \multicolumn{5}{|l|}{ Wealth index } \\
\hline Poorest & $34(12.1)$ & 247 (87.9) & I & I \\
\hline Poorer & $21(13.1)$ & $139(86.9)$ & $1.0(0.5-1.9)$ & $0.9(0.5-1.7)$ \\
\hline Middle & $25(16.8)$ & $124(83.2)$ & $1.4(0.8-2.7)$ & $1.2(0.6-2.2)$ \\
\hline Richer & $25(17.9)$ & II5 (82.I) & $1.5(0.8-2.8)$ & $1.4(0.7-2.6)$ \\
\hline Richest & $36(19.3)$ & 151 (80.7) & $1.8(1.2-3.2)$ & $1.5(0.6-2.6)$ \\
\hline \multicolumn{5}{|c|}{ Occupation of respondents } \\
\hline Not working & 59 (II.7) & $445(90.3)$ & 1 & I \\
\hline Sale \&services & $25(17.7)$ & $116(82.3)$ & $1.7(0.9-3.0)$ & $1.3(0.8-2.4)$ \\
\hline Agriculture & $38(22.2)$ & I33 (77.8) & $2.2(1.3-3.5)$ & $2.2(1.3-3.6) *$ \\
\hline Others ${ }^{\mathrm{b}}$ & $19(18.8)$ & $82(8 I .2)$ & $1.8(0.9-3.3)$ & I.3 (0.8-2.6) \\
\hline \multicolumn{5}{|l|}{ Number of ANC visit } \\
\hline 0 & $24(9.2)$ & $237(90.8)$ & I & I \\
\hline $1-3$ & $4 \mid(14.4)$ & $244(85.6)$ & $1.7(0.9-3.0)$ & $1.6(0.9-2.9)$ \\
\hline $4+$ & $76(20.5)$ & $295(79.5)$ & $2.7(1.6-4.6)$ & $2.3(1.3-4.3) *$ \\
\hline \multicolumn{5}{|l|}{ Place of delivery } \\
\hline Home & $7 \mid(13.2)$ & $465(86.8)$ & I & 1 \\
\hline Health institution & $70(18.4)$ & $3 I I(8 I .6)$ & $1.5(0.9-2.2)$ & $1.0(0.6-1.7)$ \\
\hline \multicolumn{5}{|c|}{ Desire to more children } \\
\hline Wanted & $82(13.9)$ & $509(86.1)$ & 1 & 1 \\
\hline Undecided & $5(15.6)$ & $27(84.4)$ & I.2 (0.4-3.4) & $1.2(0.4-3.6)$ \\
\hline No more wanted & $54(18.4)$ & $240(81.6)$ & $1.4(0.9-2.1)$ & $1.3(0.9-2.1)$ \\
\hline \multicolumn{5}{|l|}{ Child age in months } \\
\hline$<6$ months & $8(9.0)$ & $80(91.0)$ & I & 1 \\
\hline 6-23 months & $75(14.7)$ & $435(85.3)$ & $\mathrm{I} .8(0.8-4.0)$ & $1.7(0.8-3.9)$ \\
\hline 24 and above & $58(18.2)$ & $261(81.8)$ & $2.4(1.1-0.6)$ & $2.2(0.9-5.4)$ \\
\hline \multicolumn{5}{|c|}{ Postnatal check within 2 months of age } \\
\hline No & $113(13.9)$ & $700(86.1)$ & I & I \\
\hline Yes & $28(26.9)$ & $76(73.1)$ & $2.3(1.4-3.9)$ & $1.9(1.1-3.2) *$ \\
\hline
\end{tabular}

(Continued) 
Table 5 (Continued).

\begin{tabular}{|c|c|c|c|c|}
\hline \multirow[t]{2}{*}{ Variables } & \multicolumn{2}{|c|}{ Feeding Practices During Diarrhea } & \multirow[t]{2}{*}{ COR $(95 \% \mathrm{Cl})$} & \multirow[t]{2}{*}{ AOR $(95 \% \mathrm{Cl})$} \\
\hline & Appropriate n (\%) & Inappropriate $\mathbf{n}(\%)$ & & \\
\hline \multicolumn{5}{|l|}{ Currently breastfeeding } \\
\hline No & $51(18.3)$ & $228(8 I .7)$ & I & 1 \\
\hline Yes & $90(14.1)$ & $548(85.9)$ & $0.7(0.5-1.1)$ & $0.8(0.5-1.4)$ \\
\hline \multicolumn{5}{|l|}{ Exposure to Mass Media } \\
\hline Not at all & $81(13.8)$ & $505(86.2)$ & I & I \\
\hline Less than once a week & $47(17.9)$ & $216(82.1)$ & $1.4(0.9-2.2)$ & $1.0(0.7-1.7)$ \\
\hline At least once a week & $13(19.1)$ & $55(80.9)$ & $1.6(0.7-3.3)$ & $0.9(0.4-2.1)$ \\
\hline \multicolumn{5}{|c|}{ Visited by fieldwork for the last one year } \\
\hline No & $83(13.3)$ & $543(86.7)$ & I & I \\
\hline Yes & $58(19.9)$ & $233(80.1)$ & $1.6(1.1-2.4)$ & $1.3(0.9-2.0)$ \\
\hline
\end{tabular}

Notes: ${ }^{a}$ Others: Protestant, Catholic, traditional; ${ }^{\mathrm{b}}$ Others: skilled manual, unskilled manual, do not know. ${ }^{*}$ Statistically significant at a $\mathrm{p}$-value $<0.05$.

feeding practice more likely than mothers who had two children. ${ }^{17}$

The odds of appropriate feeding practice among children whose mothers worked in agriculture were higher compared with children whose mothers did not have work. Women who work in agriculture might have better access to diversified agricultural and animal products. Moreover, participating in work may expose mothers to peers and friends that can serve as a source of information related to feeding practice. ${ }^{17,26}$

The odds of appropriate feeding practice among children whose mothers had ANC and PNC follow-up were higher compared to children whose mothers did not have ANC and PNC follow-up. These services are a good point of contact to give counseling about child feeding practice in addition to maternal and child care. Mothers who had ANC and PNC follow-up may receive information, education, and counseling from health professionals about appropriate child feeding practices for normal child growth and during an illness such as diarrhea disease. A study in 15 sub-Saharan African countries showed PNC associated with increase breastfeeding. ${ }^{30}$ Another study supported that mothers who got counseling about child feeding and who had more than four ANC practice appropriate feeding practice. ${ }^{17,27}$

\section{Strength and Limitations of the Study}

The study used a large sample size at a national level, so that it may enhance its representativeness. Furthermore, the DHS surveys have a similar design, with similar variables in a different setting. Therefore, the result may be applied to other similar settings.

The possible limitations might be the cross-sectional nature of this study, whereby it may not explain the temporal relationship between maternal characteristics and child feeding practices. Besides, the dataset does not include important variables like social norms, beliefs, and behavior, which might have a significant effect on feeding practice. Furthermore, the feeding practice was measured by using maternal verbal responses in which there might be a social desirability bias. These drawbacks will deter the implication of our fundings, so further study should be carried out to explore the detailed practice by observing the normal meal frequency given to the baby at the time of illness.

\section{Conclusions}

Generally, appropriate feeding practice during diarrheal disease among children aged less than five years was low in Ethiopia. Maternal age, working condition, ANC and PNC follow-up were increased feeding practices during diarrhea disease. Maternal and child health services (ANC and PNC) have shown a significant positive association with feeding practice. Therefore, the government shall strengthen the existing maternal and child health service.

\section{Data Sharing Statement}

All data are available within the manuscript. Data is available on https://dhsprogram.com/data/available-datasets. $\underline{\mathrm{cfm}}$. 


\section{Acknowledgments}

The authors are grateful to Measure DHS for their support in providing the data for this project.

\section{Disclosure}

The authors report no competing interests in this work.

\section{References}

1. Okoro C, Ikediuwa U, Mgbudem F, Uwabunkonye B, Osondu B. Estimation of levels and trends of under-five mortality in sub-saharan africa: evidence from summary of birth histories of currently married women. Asian J Probab Stat. 2020;17-27. doi:10.9734/ajpas/2020/ v7i230176

2. Danzhen Y, Hug L, Ejdemyr S, Idele P, Hogan D, Mathers C. Global, regional, and national levels and trends in under- 5 mortality between 1990 and 2015, with scenario-based projections to 2030: a systematic analysis by the un inter-agency group for child mortality estimation. united nations inter-agency group for child mortality estimation (UN IGME). Lancet. 2015;386:2275-2286.

3. Berelie Y, Yismaw L, Tesfa E, Alene M. Risk factors for under-five mortality in Ethiopia: evidence from the 2016 Ethiopian Demographic and Health Survey. S Afr J Child Health. 2019;13 (3):137-140. doi:10.7196/SAJCH.2019.v13i3.1645

4. Jelliffe DB, Jelliffe EFP, World Health O; United Nations Children's Fund. Dietary management of young children with acute diarrhoea: a manual for managers of health programmes/D. 2nd. Geneva:World Health Organization;1991.

5. Troeger C, Forouzanfar M, Rao PC, et al. Estimates of global, regional, and national morbidity, mortality, and aetiologies of diarrhoeal diseases: a systematic analysis for the Global Burden of Disease Study 2015. Lancet Infect Dis. 2017;17(9):909-948. doi:10.1016/S1473-3099(17)30276-1

6. Munos MK, Walker CLF, Black RE. The effect of oral rehydration solution and recommended home fluids on diarrhoea mortality. Int J Epidemiol. 2010;39(suppl_1):i75-i87. doi:10.10 93/ije/dyq025

7. Fikadu T, Girma S. Feeding practice during diarrheal episode among children aged between 6 to 23 months in Mirab Abaya district, Gamo Gofa Zone, Southern Ethiopia. Int J Pediatr. 2018;2018:2374895.

8. Walker CLF, Perin J, Aryee MJ, Boschi-Pinto C, Black RE. Diarrhea incidence in low-and middle-income countries in 1990 and 2010 a systematic review. BMC Public Health. 2012;12(1):220. doi:10.11 86/1471-2458-12-220

9. Regassa G, Birke W, Deboch B, Belachew T. Environmental determinants of diarrhea among under-five children in Nekemte town, western Ethiopia. Ethiop J Health Sci. 2008;18:2.

10. Alemayehu M, Alemu T, Astatkie A. Prevalence and determinants of diarrhea among under-five children in benna tsemay district, south omo zone, southern ethiopia: a community-based cross-sectional study in pastoralist and agropastoralist context. Adv Public Health. 2020;2020.

11. Malik IA, Azim S, Good MJ, et al. Feeding practices for young Pakistani children: usual diet and diet during diarrhoea. J Diarrhoeal Dis Res. 1991;9(3):213-218.

12. Pantenburg B, Ochoa TJ, Ecker L, Ruiz J. Feeding of young children during diarrhea: caregivers' intended practices and perceptions. Am J Trop Med Hyg. 2014;91(3):555-562. doi:10.4269/ ajtmh.13-0235

13. Liu L, Hill K, Oza S, et al. Levels and causes of mortality under age five years. Reprod Maternal Newborn Child Health. 2016;71.
14. Radjasegarane A, Rajagopal A, Mathiyalagen P, Vasudevan K. A cross sectional study on optimal infant and young child feeding practices with reference to WHO indicators in a rural area of Puducherry. Int J Community Med Public Health. 2019;6(4):1684. doi:10.18203/2394-6040.ijcmph20191405

15. Seid S, Sendo E, Haso T, Amme S. Utilization of integrated management of neonatal and childhood illness (IMNCI) guidelines and associated factors among nurse at public health institutions in west arsi zone, South East Ethiopia. Clin Mother Child Health. 2019;16 (313):2.

16. Organization WH. Essential Nutrition Actions: Improving Maternal, Newborn, Infant and Young Child Health and Nutrition; 2013.

17. Degefa N, Tadesse H, Aga F, Yeheyis T. Sick child feeding practice and associated factors among mothers of children less than 24 months old, in Burayu Town, Ethiopia. Int J Pediatr. 2019;19:2019.

18. Gaffey MF, Wazny K, Bassani DG, Bhutta ZA. Dietary management of childhood diarrhea in low- and middle-income countries: a systematic review. BMC Public Health. 2013;13(3):S17. doi:10.11 86/1471-2458-13-S3-S17

19. Paintal K, Aguayo VM. Feeding practices for infants and young children during and after common illness. Evidence from South Asia. Matern Child Nutr. 2016;12 Suppl 1(Supp11):39-71.

20. Bhutta ZA, Das JK, Walker N, et al. Interventions to address deaths from childhood pneumonia and diarrhoea equitably: what works and at what cost? Lancet. 2013;381(9875):1417-1429. doi:10.1016/S01 40-6736(13)60648-0

21. De Onis M, Dewey KG, Borghi E, et al. The World Health Organization's global target for reducing childhood stunting by 2025: rationale and proposed actions. Matern Child Nutr. 2013;9:6-26. doi:10.1111/mcn.12075

22. Acácio S, Mandomando I, Nhampossa T, et al. Risk factors for death among children 0-59 months of age with moderate-to-severe diarrhea in Manhiça district, southern Mozambique. BMC Infect Dis. 2019;19 (1):322. doi:10.1186/s12879-019-3948-9

23. Bezabih AM, Mohammed H, Kedir A, Haile F, Redae G, Medhanyie AA. Poor feeding practices during childhood illnesses in rural pastoralist communities of afar, North Eastern Ethiopia: a cross sectional study. East Afr J Health Sci. 2019;1(1):41-54.

24. Central Statistical Agency (CSA) [Ethiopia] and ICF. Ethiopia Demographic and Health Survey 2016. Addis Ababa, Ethiopia, and Rockville, Maryland, USA: CSA and ICF. 2016; 2016. Available from: https://dhsprogram.com. Accessed February 12, 2021.

25. Assefa D, Wassie E, Getahun M, Berhaneselassie M, Melaku A. Harmful traditional practices. Carter Centre. 2005.

26. Tassew AA, Tekle DY, Belachew AB, Adhena BM. Factors affecting feeding 6-23 months age children according to minimum acceptable diet in Ethiopia: a multilevel analysis of the Ethiopian Demographic Health Survey. PLoS One. 2019;14(2):2. doi:10.1371/journal.pone. 0203098

27. Fikadu T, Girma S. Feeding practice during diarrheal episode among children aged between 6 to 23 months in Mirab Abaya district, Gamo Gofa Zone, Southern Ethiopia. Int J Pediatr. 2018;2018:2018. doi:10.1155/2018/2374895

28. Paintal K, Aguayo VM. Feeding practices for infants and young children during and after common illness. Evidence from South Asia. Matern Child Nutr. 2016;12:39-71. doi:10.1111/mcn.12222

29. Das SK, Nasrin D, Ahmed S, et al. Health care-seeking behavior for childhood diarrhea in Mirzapur, rural Bangladesh. Am J Trop Med Hyg. 2013;89(1_Suppl):62-68. doi:10.4269/ajtmh.13-0107

30. Khan SM, Speizer IS, Singh K, Angeles G, Twum-Danso NA, Barker P. Does postnatal care have a role in improving newborn feeding? A study in 15 sub-Saharan African countries. J Glob Health. 2017;7(2):2. doi:10.7189/jogh.07.020506 


\section{Publish your work in this journal}

Pediatric Health, Medicine and Therapeutics is an international, peerreviewed, open access journal publishing original research, reports, editorials, reviews and commentaries. All aspects of health maintenance, preventative measures and disease treatment interventions are addressed within the journal. Practitioners from all disciplines are invited to submit their work as well as healthcare researchers and patient support groups. The manuscript management system is completely online and includes a very quick and fair peer-review system. Visit http://www.dovepress.com/testimonials.php to read real quotes from published authors. 